Article

\title{
Type of Explant Affects In Vitro Development and Multiplication Success of the Rare Halophyte Plant Honckenya Peploides L. Ehrh
}

\author{
Danuta Kulpa $^{1, * \mathbb{D}}$, Mariola Wrobel ${ }^{2}$ and Martyna Bednarek $^{1}$ \\ 1 Department of Plant Genetic, Breeding and Biotechnology, Faculty of Environmental Management and \\ Agriculture, West Pomeranian University of Technology, Słowackiego 17, 71-434 Szczecin, Poland; \\ martyna.bednarek@zut.edu.pl \\ 2 Department of Meteorology, Botany and Green Areas Management, Faculty of Environmental Management \\ and Agriculture, West Pomeranian University of Technology, Słowackiego 17, 71-434 Szczecin, Poland; \\ mariola.wrobel@zut.edu.pl \\ * Correspondence: danuta.kulpa@zut.edu.pl
}

Received: 6 October 2020; Accepted: 6 November 2020; Published: 9 November 2020

\begin{abstract}
The sea sandwort-Honckenya peploides (L.) Ehrh. is-a rare halophilous plant growing on dunes and is an endangered species on the Polish coast. It contributes to the stabilization of volatile sandy substrate, facilitating the colonization of other species. The present study determined the reaction of two types of explant: apical shoot fragments and fragments from a lower portion of the shoot. Apical shoot fragments were used to propagate and root sea sandwort plants due to the positive impact on the development of shoots and roots. Regardless of the plant growth regulators applied in the medium, the lateral meristems on the explants from the lower parts of the shoot stopped growing, and then yellowed and died out. Apical fragments of shoots developed higher and more numerous shoots and longer and more numerous roots than explants, which were fragments collected from lower parts of shoots. The findings indicated that propagation should be conducted on Murashige and Skoog medium with the addition of $1 \mathrm{mg} \cdot \mathrm{dm}^{-3}$ kinetin, whereas shoots with their apical fragments should be rooted with the addition of $1.5 \mathrm{mg} \cdot \mathrm{dm}^{-3} 1$-naphthaleneacetic acid. The results also showed that the addition of $\mathrm{NaCl}$ at concentrations of 25 and $50 \mathrm{mM}$ did not restrict their growth, thereby indicating the tolerance of the plant to soil salinity. However, an increase in the concentration of $\mathrm{NaCl}$ in the medium to $75 \mathrm{mM}$ restricted the development of plants, and the shoots were lower and roots were shorter and less numerous.
\end{abstract}

Keywords: micropropagation; psammophytes; halophytes; topophysis; salinity; position of explants; $\mathrm{NaCl}$

\section{Introduction}

Halophytes or halophilous plants are susceptible to the alterations of habitat conditions, and in particular, to reduced salinity and competition from other expansive species. The distribution of coastal halophytes is influenced by the regular supply of saline seawater during tides or high levels of stormwater [1,2]. Sea sandwort Honckenya peploides (L.) Ehrh. of the pink family Caryophyllaceae is an example of an obligatory halophyte requiring considerable soil salinity [3-5]. This plant has a subpolar distribution, stretching from the Arctic to the temperate zone in Western Europe, North America, and northwest Russia to Japan [6,7]. It occurs in the northern temperate zone between $30^{\circ}$ and $80^{\circ}$ latitude [6]. On coastal dunes, H. peploides colonizes the upper beach, where it forms small mounds known as embryo dunes, thereby stabilizing the volatile sandy substrate and facilitating colonization by other species (Figures 1 and 2) [8-11]. It is the key species involved in the formation of permanent 
accumulative forms, which may transform into new dune ridges. In Poland, the sea sandwort has been designated as near-threatened and included in the Polish red list of ferns and flowering plants [12]. The existence of this rare plant in the Polish Baltic Sea coast is threatened by natural factors, such as storms and marine abrasion of beach habitats, and primarily affected by human activities, including mass tourism, recreational usage of sandy beaches, and transformation of dune habitats as well as development of the coast [13].

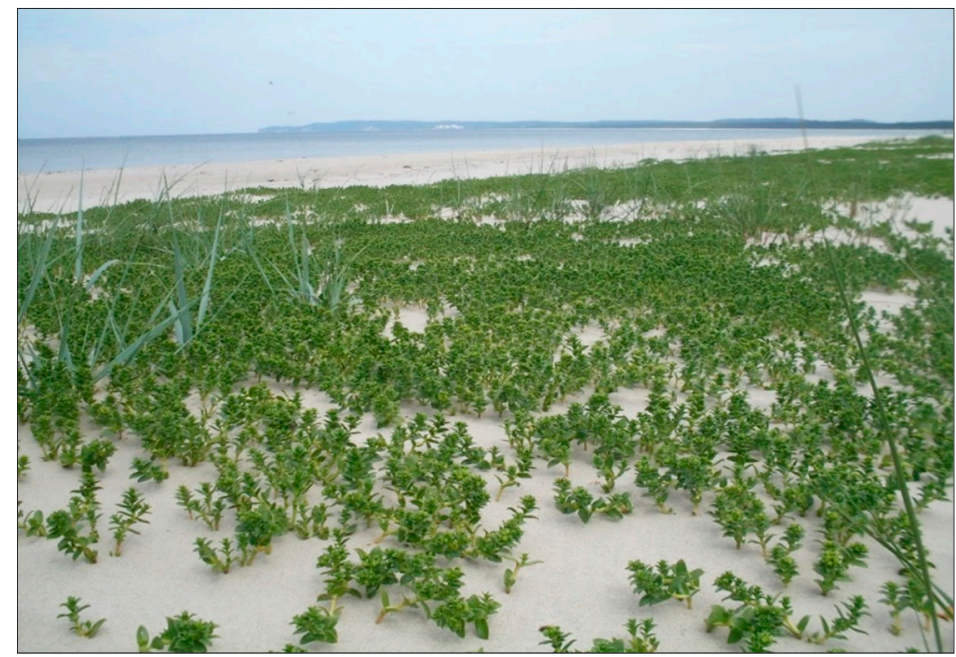

Figure 1. Honckenya peploides on the west coast of the Baltic Sea.

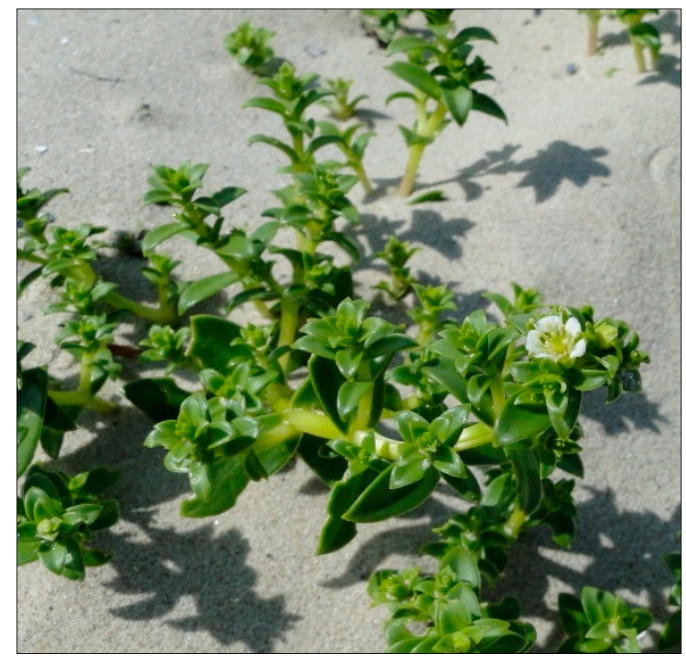

Figure 2. Flowering of Honckenya peploides.

The sea sandwort is a utility plant in many countries. Juvenile sandwort shoots are consumed as vegetables, either in the raw or cooked form. They have a sour taste and a delicate flavor [14]. Sea sandwort plants have a high content of vitamins A and C. The leaves are pickled, and in Iceland, the entire plant is immersed in a sour whey and left to ferment. The alcoholic beverage thus obtained tastes similar to olive oil. The seeds, which are difficult to collect, are ground and added to flour. The Inuit people consume sandwort due to its medicinal properties. They collect the plant before flowering, in early summer. Juicy leaves and stems are cooked and consumed with seal oil [15].

Sea sandwort does not only propagate generatively but also vegetatively through buds on underground rootstock $[5,16]$. In vitro propagation is a method used to protect endangered species. It requires the precise selection of factors influencing the growth and development of plants under laboratory conditions, particularly the contents of plant growth regulators in medium to meet the 
needs of a given species. At present, the subject literature contains only a few studies on the possibility of in vitro propagation of halophytes and psammophytes owing to their long life cycles, heterozygosity, and difficulty in establishing in vitro cultures [17]. The problems associated with the reproduction of plants in this group include low efficiency of multiplication in in vitro cultures [18], high sensitivity to the effects of cytokinins usually added to the media during the multiplication stage in in vitro cultures, and frequent occurrence of hyperhydicity [19-22].

It was found that for several halophytes, $\mathrm{NaCl}$ addition to the medium in low concentrations $(25 \mathrm{mM})$ promotes plant growth, both by increasing the number of leaves and improving the root system $[23,24]$. Other reports indicated that leaves and roots reacted differently to salt stress and were more sensitive to $\mathrm{NaCl}$ than the leaves. This may be explained by the hypothesis that the roots, which are the first part of a plant to encounter soil salinity, are more markedly affected by saline conditions than the leaves [25].

A critical stage of multiplication in in vitro cultures is rooting, which is particularly difficult in the case of halophytes. Very often, in the case of these, despite the high multiplication factor, the effectiveness of the culture is low, due to the small percentage of plants adapted to the in vivo conditions due to the poor development of the root system. During the rooting stage of many halophilic plants, auxins, especially 1-naphthaleneacetic acid (NAA), are added to the media [26,27]. Based on this, it can be assumed that the simultaneous application of an auxin and $\mathrm{NaCl}$ may have a beneficial effect on the rooting of $\mathrm{H}$. peploides shoots. Determining the optimal $\mathrm{NaCl}$ content in the substrate, however, is not easy. In the studies by Ben Amour [23] on the microproduction of the halophilic species Crithmum maritimum, the increase in the above-ground and the underground parts was observed when plants were grown on a $50 \mathrm{mM}$ medium. In the study of Joshi et al. [26] on the halophilic plant Salicornia brachiata, the salt content accumulating multiplication and rooting was much higher [250 and $500 \mathrm{mM}$ ].

Therefore, this study aimed to develop in vitro propagation methods for the sea sandwort $(H$. peploides (L.) Ehrh.). Particular attention was paid to the type of explants and the content of cytokinins, auxin NAA and $\mathrm{NaCl}$ in the medium.

\section{Results}

Initiation stage. Two types of primary explants—shoot fragments and seeds-were introduced onto the media at the initiation stage. None of the shoot explants commenced growth, whereas $12 \%$ of the seeds placed on the medium were found to germinate (Figures 3 and 4). The remaining seeds were infected and did not germinate.

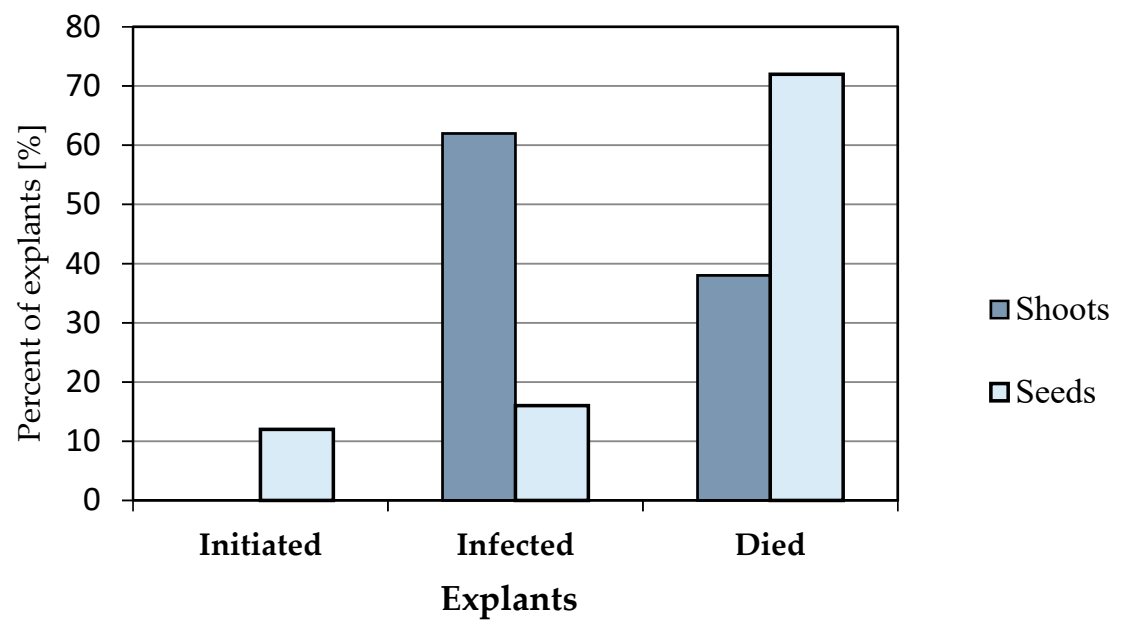

Figure 3. Percentage of explants [\%] initiating growth, infected, and dead. 


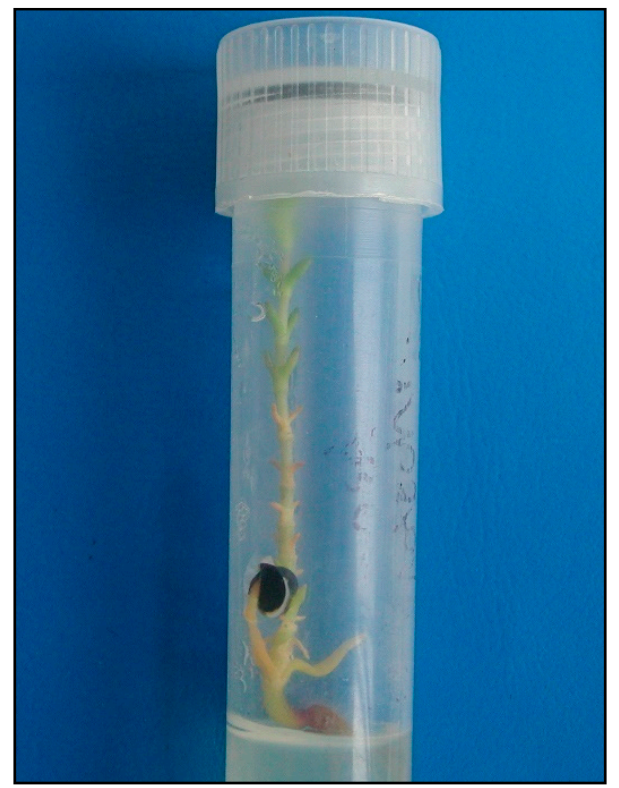

Figure 4. Micropropagation of Honckenya peploides: germinated seed.

Propagation stage. At the propagation stage, the sea sandwort plants were characterized by a different appearance than that observed under natural conditions, regardless of the concentration and type of cytokinin added. The shoots were found to be yellowish, beginning from the plant base, indicating the symptoms of vitrification, particularly in the media containing the highest concentration of cytokinin (Figure 5).

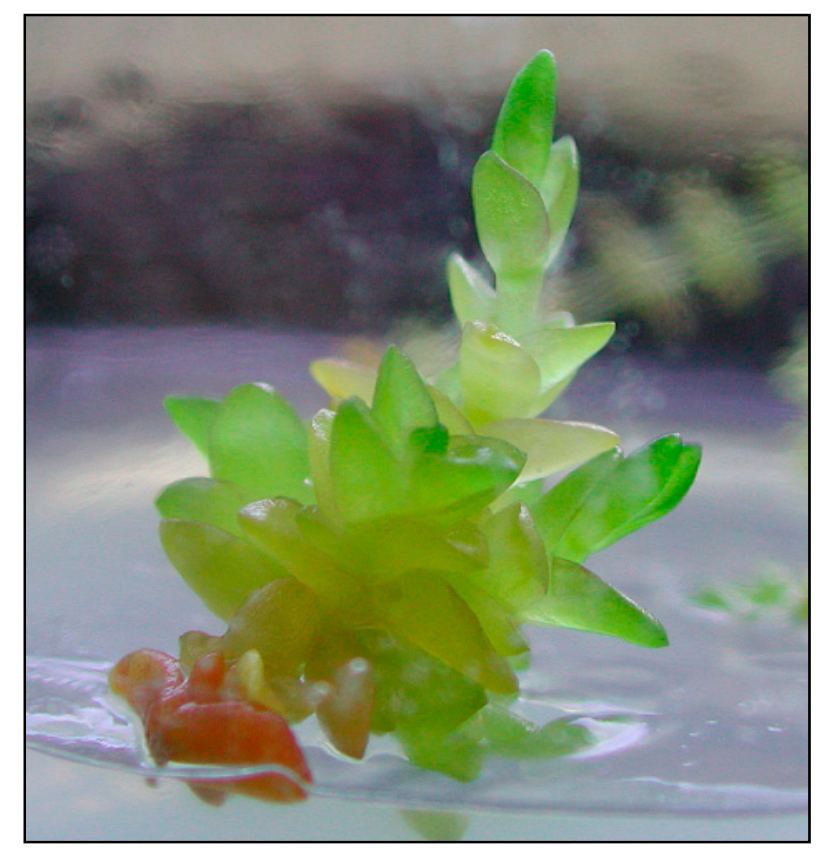

Figure 5. Top explant with symptoms of hyperhydicity regenerated on the Murashige and Skoog (MS) medium supplemented with $2 \mathrm{mg} \cdot \mathrm{dm}^{-3}$ of 6-benzylaminopurine (BAP).

The type and concentration of cytokinin added to the medium had a significant impact on the shoot length of sandwort (Table 1). Explants introduced in the media supplemented with kinetin (KIN) developed shoots with a height similar to plants propagated on the control medium ( 0.5 and $\left.2 \mathrm{mg} \cdot \mathrm{dm}^{-3}\right)$ or were even taller than them $\left(0.75\right.$ and $\left.1 \mathrm{mg} \cdot \mathrm{dm}^{-3}\right)$. In turn, the remaining cytokinins 
observed between shoot explants and apical fragments (7.69 and $26.10 \mathrm{~mm}$, respectively). Regardless of the NAA concentration and explant type, sandwort plants developed one shoot.

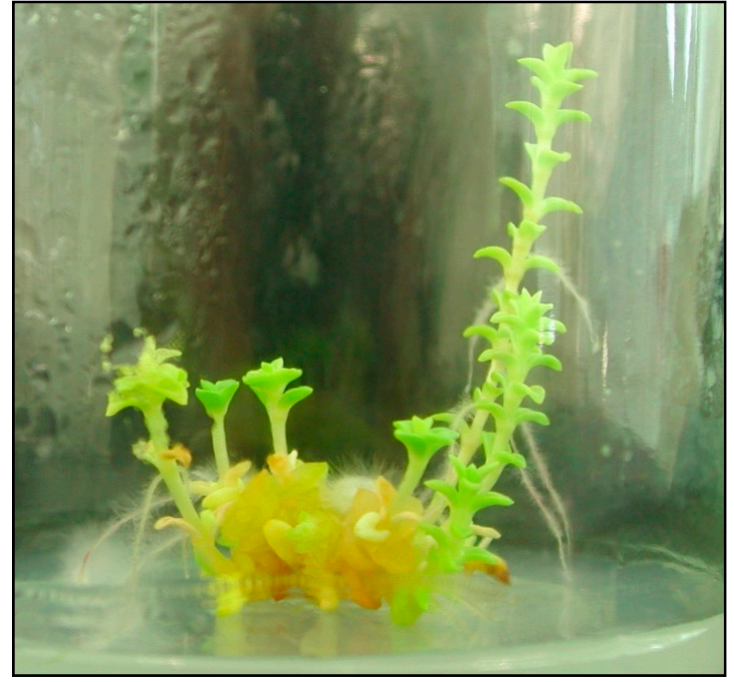

(a)

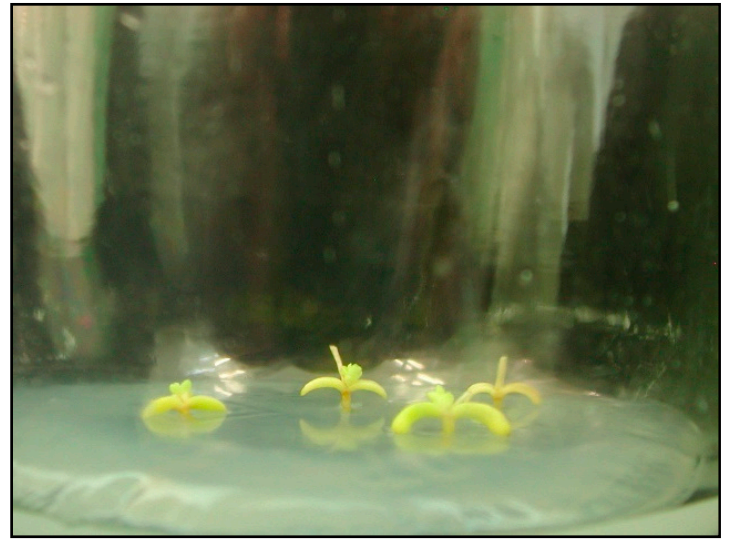

(b)

Figure 6. Top (a) and shoot (b) explant propagated on the MS medium supplemented with $1 \mathrm{mg} \cdot \mathrm{dm}^{-3}$ of kinetin (KIN) after 6 weeks of growth.

Table 2. Effects of type explants and 1-naphthaleneacetic acid (NAA) content on the rooting of Honckenya peploides.

\begin{tabular}{ccccccccccccc}
\hline $\begin{array}{c}\text { NAA Content } \\
{\left[\mathbf{m g} \cdot \mathbf{d m}^{-\mathbf{3}} \text { ] }\right.}\end{array}$ & \multicolumn{3}{c}{ Plant Height $[\mathbf{m m}]$} & \multicolumn{3}{c}{ Number of Shoots } & \multicolumn{3}{c}{ Roots Length [mm] } & \multicolumn{3}{c}{ Number of Roots } \\
\cline { 2 - 14 } & Shoot & Top & Mean & Shoot & Top & Mean & Shoot & Top & Mean & Shoot & Top & Mean \\
\hline $\mathbf{0}$ & 3.83 & 19.73 & $\mathbf{1 1 . 7 8}$ & 1.00 & 1.00 & $\mathbf{1 . 0 0}$ & 1.67 & 6.23 & $\mathbf{3 . 9 5}$ & 1.00 & 1.93 & $\mathbf{1 . 4 7}$ \\
$\mathbf{0 . 5}$ & 6.06 & 42.63 & $\mathbf{2 4 . 3 4}$ & 1.00 & 1.00 & $\mathbf{1 . 0 0}$ & 3.22 & 20.92 & $\mathbf{1 2 . 0 7}$ & 1.11 & 2.63 & $\mathbf{1 . 8 7}$ \\
$\mathbf{1}$ & 6.54 & 40.83 & $\mathbf{2 3 . 6 9}$ & 1.00 & 1.00 & $\mathbf{1 . 0 0}$ & 2.73 & 21.43 & $\mathbf{1 2 . 0 8}$ & 1.81 & 4.13 & $\mathbf{2 . 9 7}$ \\
$\mathbf{1 . 5}$ & 9.68 & 67.17 & $\mathbf{3 8 . 4 3}$ & 1.00 & 1.00 & $\mathbf{1 . 0 0}$ & 6.55 & 17.60 & $\mathbf{1 2 . 0 8}$ & 2.37 & 6.17 & $\mathbf{4 . 2 7}$ \\
\hline Mean & $\mathbf{6 . 5 3}$ & $\mathbf{4 2 . 5 9}$ & & $\mathbf{1 . 0 0}$ & $\mathbf{1 . 0 0}$ & & $\mathbf{3 . 5 4}$ & $\mathbf{1 6 . 5 5}$ & & $\mathbf{1 . 5 7}$ & $\mathbf{3 . 7 2}$ \\
\hline LSD $_{0.05}$ & & & & & & & & & & & \\
Media (M) & & 1.18 & & non signifficant. & & 1.05 & & & 0.92 \\
Explants (E) & & 3.37 & & non signifficant & & 4.27 & & & 0.98 \\
MxE & & 1.42 & & non signifficant & & 1.23 & & & 0.85 \\
ExM & & 3.76 & & non signifficant & & 5.62 & & & 0.38 \\
\hline
\end{tabular}

Independent of the concentration, the addition of NAA stimulated rhizogenesis. The type of explant used also had a significant impact on the root length (Figure $7 \mathrm{~b}$ ). Apical explants developed a higher number (3.72) of roots, and the roots were longer (19.05). The highest number of roots $(2.97$ and 4.27, respectively) was developed by explants introduced onto media supplemented with 1 and $1.5 \mathrm{mg} \cdot \mathrm{dm}^{-3} \mathrm{NAA}$, and the roots were also the longest $(12.08 \mathrm{~mm})$. Moreover, the interaction of the factors discussed turned out to be significant. The number of roots regenerated by apical explants was highest when the explants were introduced onto media supplemented with 1 and $1.5 \mathrm{mg} \cdot \mathrm{dm}^{-3} \mathrm{NAA}$ (4.13 and 6.17, respectively).

Effects of $\mathrm{NaCl}$. Sea sandwort growing on media containing 25 and $50 \mathrm{mM} \mathrm{NaCl}$ developed shoots and root system similar to the control plants (Table 3). Increasing the soil salinity to $75 \mathrm{mM}$ resulted in the development of the shortest shoots and shorter and less numerous roots. Independent of the $\mathrm{NaCl}$ content in the medium, sandwort plants developed a similar number of shoots (ranging from 1.00 to 1.14). Moreover, the plants developed from apical explants were taller and developed a higher number of longer roots than those developed from shoot explants. 


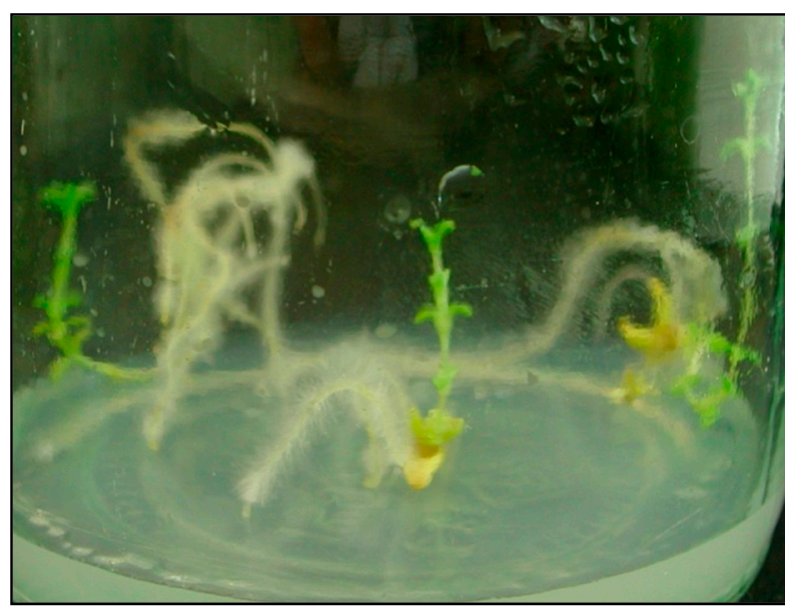

(a)

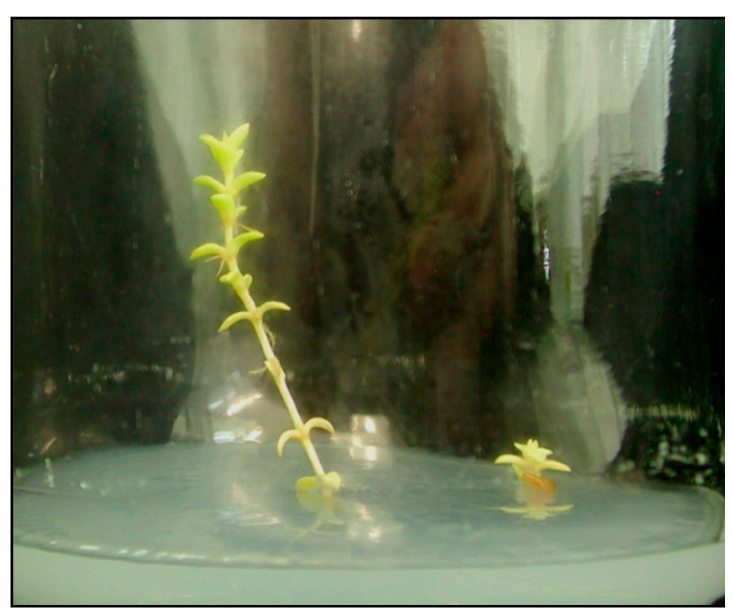

(b)

Figure 7. Rooting stage (6 weeks of growth). Top explants rooted on the medium with the addition of $1.5 \mathrm{mg} \cdot \mathrm{dm}^{-3} \mathrm{NAA}(\mathbf{a})$. Top (left) and shoot (right) explants rooted on the medium with the addition of $1 \mathrm{mg} \cdot \mathrm{dm}^{-3} \mathrm{NAA}(\mathbf{b})$.

Table 3. Effects of type of explant on the multiplication of Honckenya peploides propagated on MS media with the addition of $1.5 \mathrm{mg} \cdot \mathrm{dm}^{-3} \mathrm{NAA}$ and varied $\mathrm{NaCl}$ content.

\begin{tabular}{|c|c|c|c|c|c|c|c|c|c|c|c|c|}
\hline \multirow{2}{*}{$\begin{array}{c}\mathrm{NaCl} \\
\text { Content } \\
{[\mathrm{mM}]}\end{array}$} & \multicolumn{3}{|c|}{ Plant Height [mm] } & \multicolumn{3}{|c|}{ Number of Shoots } & \multicolumn{3}{|c|}{ Roots Length [mm] } & \multicolumn{3}{|c|}{ Number of Roots } \\
\hline & Shoot & Top & Mean & Shoot & Top & Mean & Shoot & Top & Mean & Shoot & Top & Mean \\
\hline 0 & 10.22 & 65.21 & 37.72 & 1.00 & 1.00 & 1.00 & 7.05 & 18.25 & 12.65 & 2.45 & 7.02 & 4.74 \\
\hline 25 & 11.21 & 64.25 & 37.73 & 1.00 & 1.00 & 1.00 & 7.58 & 17.85 & 12.72 & 1.56 & 5.64 & 3.60 \\
\hline 50 & 10.05 & 61.32 & 35.69 & 1.00 & 1.14 & 1.07 & 6.98 & 18.24 & 12.61 & 1.78 & 5.29 & 3.54 \\
\hline 75 & 8.12 & 45.25 & 26.69 & 1.11 & 1.00 & 1.06 & 2.02 & 6.25 & 4.14 & 0.65 & 2.28 & 1.47 \\
\hline Mean & 9.90 & 59.01 & & 1.03 & 1.05 & & 5.91 & 15.15 & & 1.61 & 5.06 & \\
\hline \multicolumn{13}{|l|}{$\operatorname{LSD}_{0.05}$} \\
\hline Media (M) & & \multicolumn{3}{|c|}{ non signifficant } & \multicolumn{3}{|c|}{2.36} & \multicolumn{3}{|c|}{1.32} \\
\hline Explants (E) & \multicolumn{3}{|c|}{2.35} & \multicolumn{3}{|c|}{ non signifficant } & \multicolumn{3}{|c|}{1.06} & \multicolumn{3}{|c|}{0.56} \\
\hline MxE & \multicolumn{3}{|c|}{4.92} & \multicolumn{3}{|c|}{ non signifficant } & \multicolumn{3}{|c|}{4.25} & \multicolumn{3}{|c|}{1.45} \\
\hline ExM & \multicolumn{3}{|c|}{3.25} & \multicolumn{3}{|c|}{ non signifficant } & \multicolumn{3}{|c|}{2.56} & \multicolumn{3}{|c|}{0.82} \\
\hline
\end{tabular}

\section{Discussion}

The present study determined the impact of cytokinins BAP, KIN, and $\mathrm{mT}$ on the propagation of plants, as well as NAA on the growth and rooting of the sea sandwort under in vitro cultures. The experiment also assessed the reaction of two types of explant-apical fragments and single-node fragments obtained from the lowest shoot portions-to the addition of plant growth regulators to media. In addition, the response of explants to the addition of $\mathrm{NaCl}$ to medium was examined.

It was observed that the type and concentration of cytokinin added to medium and the type of explant used had a significant impact on the length of sandwort shoots. The Murashige and Skoog (MS) medium containing KIN at the concentration of $1 \mathrm{mg} \cdot \mathrm{dm}^{-3}$ was found to be the best for the propagation stage. The growth of the above-ground parts was strongly stimulated by this cytokinin, and apical explants developed as many as 4.33 shoots. KIN was also identified to be positively influencing the development of the above-ground part in the study of Kharrazi et al. [22] on Dianthus caryophyllus, another plant belonging to the pink family. It was observed that the addition of $1 \mathrm{mg} \cdot \mathrm{dm}^{-3} \mathrm{KIN}$ increased the length of shoots. Simona et al. [28] investigated the impact of growth regulators on Dianthus chinensis. When KIN was used at a concentration of $0.5-2.5 \mathrm{mg} \cdot \mathrm{dm}^{-3}$, the plants developed the highest shoot; however, unfortunately, the highest percentage of vitrified plants was also obtained. In the present study, vitrification symptoms were observed in the population of plants propagated on media supplemented with the highest cytokinin concentrations. 
The influence of the addition of $0.5,1$, and $1.5 \mathrm{mg} \cdot \mathrm{dm}^{-3} \mathrm{NAA}$ (1-naphthaleneacetic acid) to the medium was determined in the subsequent study stage. It was found that the addition of the NAA auxin to medium stimulated rhizogenesis. The highest number of shoots was noticed on media added with 1 and $1.5 \mathrm{mg} \cdot \mathrm{dm}^{-3} \mathrm{NAA}$. Ali et al. [29] concluded that medium supplemented with $1 \mathrm{mg} \cdot \mathrm{dm}^{-3}$ NAA is the best for in vitro rooting of $D$. caryophyllus.

In both study stages, a considerable difference was observed between the development of plants from apical explants and explants from the remaining portions of the shoot. The phenomenon of variable growth and development of seedlings based on their location in the mother plant is referred to as topophysis. The primary explant, which gives a start to a culture, transmits the memory of its status in the mother plant to the conditions of an in vitro culture. The study of Zalewska et al. [30] analyzed the impact of topophysical location of explants on the in vitro shoot regeneration efficacy in chrysanthemum. The authors examined the regeneration capacity of explants isolated from three topophysical zones: distal, central, and proximal. A sevenfold higher number of adventitious shoots were developed on the explants isolated from the distal proximal zone than from the central zone. $\mathrm{Lu}$ et al. [31] demonstrated that a higher number of adventitious shoots in chrysanthemum in vitro was formed from stem segments in the upper portions of shoots growing under in vivo conditions. In the present study, it was found that the explants isolated from the apical portion of shoots developed taller shoots, with longer and more numerous roots. On the other hand, the explants isolated from the lower portions of shoot attained a very small size, were yellowed, and withered. Such a large difference may stem from the adaptation of sandwort to inhabit dunes. During the stabilization of volatile sand and formation of the first aeolian dune forms, the sea sandwort exhibits high resistance to sand burying, and then it produces longer shoots that rise from underneath the layer of sand and the thick root system stabilizes the sand. The dune grows along with the growing sandwort patch. (Explants collected from there could have a higher growth rate.) Such shoots can be referred to as vegetative and are used for rapid colonization of new areas and formation of accumulative forms. The inflorescences appear only on older shoots and stabilized embryo dunes (generative shoots, and thus, the poorer growth rate of explants collected from flowering shoots). By expanding and attaining greater height over time, embryo dunes become an unfavorable place for sandwort; the limit dune height stabilized by sandwort is $0.5-1 \mathrm{~m}$. Then, the sandwort individuals wither, and their underground shoots (rootstocks) and root system decompose, and they are replaced by new species (grasses) associated with ongoing succession. In a way, the sandwort is forced to colonize new beach surfaces in the direction of the sea [32].

In vitro propagation of halophilous plants is associated with several challenges. Addition of $\mathrm{NaCl}$ to medium was extremely critical for the propagation of another halophilous plant, Salicornia brachiata, under in vitro conditions by Joshi et al. [26]. In contrast to the study of Singh et al. [33] and Joshi et al. [34], in the present study the addition of $\mathrm{NaCl}$ to medium at concentrations of 25 and $50 \mathrm{mM}$ neither stimulated the development of Honckenya nor had any negative impact on its growth, which may suggest the tolerance of the plant to soil salinity. However, increasing the soil salinity to $75 \mathrm{mM}$ resulted in the development of the shortest shoots and shorter and less numerous roots.

\section{Conclusions}

This is the first study to report the methods of in vitro propagation of sea sandwort. The use of apical parts of shoots to propagate and root the sea sandwort (H. peploides (L.) Ehrh.) plants seems to be ideal with a positive impact on the development of shoots and roots. Propagation should be conducted on MS medium with the addition of $1 \mathrm{mg} \cdot \mathrm{dm}^{-3} \mathrm{KIN}$, whereas rooting should be performed with $1.5 \mathrm{mg} \cdot \mathrm{dm}^{-3} \mathrm{NAA}$. Addition of salt to medium does not have a positive impact on the in vitro development of $H$. peploides. The method developed can be used for propagating plants of such a high value for preserving a good state of the coastal environment. 


\section{Materials and Methods}

\subsection{Plant Material}

The starting materials for the experiment were seeds and 1-cm shoot fragments of the sea sandwort $(H$. peploides (L.) Ehrh.) (Figures 1, 2 and 8a,b) collected from the above-ground shoots growing on embryo dunes at the beach section between 423 and 422 km of the Polish Baltic Sea coast (N53.91609; E14.30809).

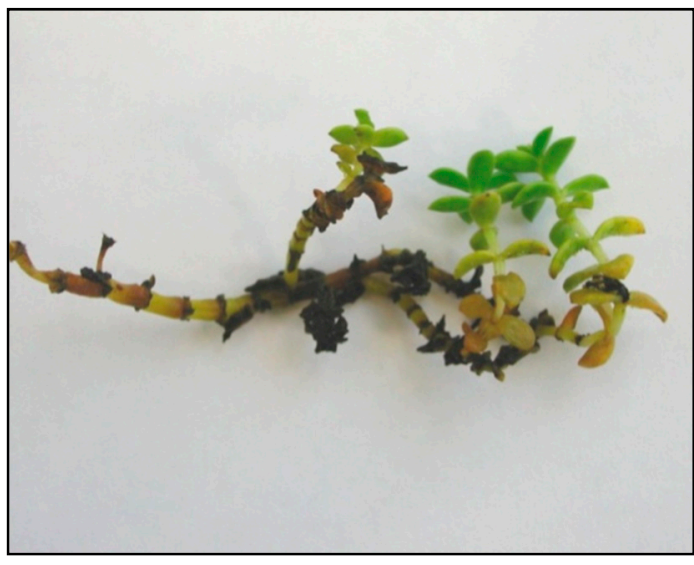

(a)

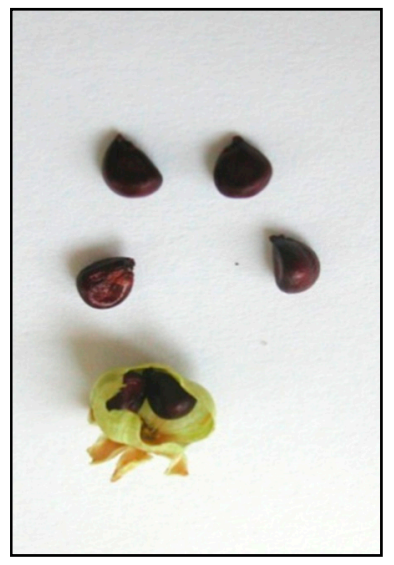

(b)

Figure 8. Starting material for tests: shoots (a) and seeds (b).

\subsection{Culture Initiation and Stabilization Stage}

The seeds and shoots were initially disinfected by rinsing in water containing a few drops of detergent. Subsequently, they were immersed in $70 \%$ ethanol for $30 \mathrm{~s}$, and then in $10 \%$ sodium hypochlorite for $15 \mathrm{~min}$, and were rinsed with sterile water three times. Explants were placed one by one into $10 \mathrm{~mL}$ test tubes, each containing $2 \mathrm{~mL}$ of MS medium [34]. After 6 weeks, the number of explants that initiated growth and were not infected were determined.

\subsection{Propagation Stage}

During this stage, as well as in the subsequent experimental stages, two types of explant were used: apical (top) shoot fragments measuring $\sim 0.5 \mathrm{~cm}$, containing apical meristem, and shoot fragments with the same length, collected from the bottom part of shoots with lateral meristems. The shoot fragments had one or two leaves. They were placed into jars containing MS media supplemented with cytokinins: BAP (6-benzylaminopurine), KIN (kinetin), or $\mathrm{mT}$ (meta-topoline)at a concentration of $0.5,0.75,1$, and $2 \mathrm{mg} \cdot \mathrm{dm}^{-3}$. Plants propagated on the MS medium without the addition of plant growth regulators constituted the control group.

\subsection{Rooting Stage}

The apical shoot fragments were used as explants and multiplied twice on the mineral medium according to Murashige and Skoog (1962) with the addition of $1 \mathrm{mg} \cdot \mathrm{dm}^{-3} \mathrm{KIN}$. Explants obtained from these 6-week-old plants were used to set up the next stage of the experiment. Two types of explant, as in the preceding study stages were placed on MS media supplemented with NAA at a concentration of $0.5,1$, and $1.5 \mathrm{mg} \cdot \mathrm{dm}^{-3}$, respectively. Plants propagated on the MS medium without the addition of plant growth regulators constituted the control group.

\subsection{Effect of $\mathrm{NaCl}$}

The starting material for the establishment of the experiment comprised 6-week-old plant shoots previously propagated on the MS medium supplemented with $1.5 \mathrm{mg} \cdot \mathrm{dm}^{-3}$ NAA. Two types of 
explant were obtained from them, as in the preceding study stages, and were placed on the MS media supplemented with $1.5 \mathrm{mg} \cdot \mathrm{dm}^{-3} \mathrm{NAA}$ and $\mathrm{NaCl}$ at variable concentrations $(25,50$, and $75 \mathrm{mM})$.

\subsection{Culture Conditions}

In all stages of the study, the media were supplemented with $30 \mathrm{~g} \cdot \mathrm{dm}^{-3}$ sucrose, $8 \mathrm{~g} \cdot \mathrm{dm}^{-3}$ agar, and $0.1 \mathrm{~g} \cdot \mathrm{dm}^{-3}$ inositol. Plant growth regulators were added to the medium before its $\mathrm{pH}$ was established at $5.7 \pm 0.1$ using $1 \mathrm{M}$ solutions of $\mathrm{HCl}$ and $\mathrm{NaOH}$. The test tubes and jars with media were sterilized in an autoclave at a temperature of $121^{\circ} \mathrm{C}$ and a pressure of $0.1 \mathrm{hPa}$ for $20 \mathrm{~min}$. The cultures were performed in a growth chamber at $24^{\circ} \mathrm{C} \pm 1{ }^{\circ} \mathrm{C}$, illuminated with a white fluorescent light having an intensity of $40 \mu \mathrm{EM}^{-2} \mathrm{~s}^{-1}$ PAR. A 16-h photoperiod and 8-h darkness cycle was applied. MS medium without the addition of plant growth regulators constituted the control group in each stage. During each experiment, apart from the culture initialization stage, the cultures were carried out in $330 \mathrm{~mL}$ jars containing $30 \mathrm{~mL}$ of medium. After 6 weeks, the height of plants $(\mathrm{mm})$, number of developed lateral buds, and number and length of roots $(\mathrm{mm})$ were determined.

\subsection{Statistical Analysis}

At the initiation stage, the experiment was conducted in a one-factor completely randomized design. It was performed in four replications with 50 explants each. In the next stages, the experiment was conducted in a two-factor completely randomized design. Each treatment at these stages consisted of 35 explants (seven replications of five explants each). An analysis of variance followed by Tukey's test $(p \leq 0.05)$ was performed. The homogeneous groups between the examined combinations were labeled with successive letters of the alphabet. The percentage data were transformed to arc-sin before the analysis.

Author Contributions: D.K. and M.W. designed the research. M.W. provided the starting material. D.K. and M.B. raised the in vitro plants for the experiments and performed the experiments. D.K., M.B., and M.W. carried out the statistical analyses, interpreted the data, and wrote the paper. All authors have read and agreed to the published version of the manuscript.

Funding: This work was supported by the West Pomeranian University of Technology of grants nr 503-07-081-09/4.

Conflicts of Interest: The authors declare no conflict of interest.

\section{Abbreviations}

MS Murashige and Skoog

NAA 1-naphthaleneacetic acid

BAP 6-benzylaminopurine

KIN kinetin

$\mathrm{mT} \quad$ meta-topoline

\section{References}

1. Wróbel, M.; Banaś-Stankiewicz, U. Factors responsible for rapid diminishing of endangered grass plant Elymus farctus subsp. boreoatlanticus in phytocoenoses on dunes coast of Baltic Sea. Polish J. Ecol. 2019, 67, 53-61. [CrossRef]

2. Garcia-Mora, M.R.; Gallego-Fernandez, J.B.; Garcia-Novo, F. Plant functional types in coastal foredunes in relation to environmental stress and disturbance. J. Veg. Sci. 1999, 10, 27-34. [CrossRef]

3. Cerantola, S.; Bessieres, M.A.; Magne, C.; Deslandes, E. Occurrence of the unusual amino acid N5-(hydroxymethyl-2, 5-dihydro-2-furyl)-L-allo- $\gamma$-hydroxyglutamine in Honkenya peploides (L.) Ehrh. Biochem. Syst. Ecol. 2005, 33, 1187-1189. [CrossRef]

4. Doing, H. Coastal fore-dune zonation and succession in various parts of the world. In Ecology of Coastal Vegetation. Advances in Vegetation Science; Beeftink, W.G., Rozema, J., Huiskes, A.H.L., Eds.; Springer: Dordrecht, The Netherlands, 1985. 
5. Sánchez-Vilas, J.; Retuerto, R. Sex-specific physiological, allocation and growth responses to water availability in the subdioecious plant Honckenya peploides. Plant Biol. 2009, 11, 243-254. [CrossRef]

6. Hultén, E.; Fries, M. Atlas of North European Vascular Plants; Koeltz Scientific Books: Köningstein, Germany, 1986.

7. Hultén, E. Flora of Alaska and Neighboring Territories: A Manual of the Vascular Plants; Stanford University Press: Stanford, CA, USA, 1968.

8. Walmsley, C.A.; Davy, A.J. Germination characteristics of shingle beach species, effects of seed ageing and their implications for vegetation restoration. J. Appl. Ecol. 1997, 196, 131-142. [CrossRef]

9. Houle, G. Interactions between resources and abiotic conditions control plant performance on subarctic coastal dunes. Am. J. Bot. 1997, 84, 1729-1737. [CrossRef]

10. Árnason, S.H.; Thorsson, A.T.; Magnússon, B.; Philipp, M.; Adsersen, H.; Anamthawat-Jónsson, K. Spatial genetic structure of the sea sandwort (Honckenya peploides) on Surtsey: An immigrant's journey. Biogeosciences 2014, 11, 6495-6507. [CrossRef]

11. Gagne, J.M.; Houle, G. Factors Responsible For Honckenya peploides (Caryophyllaceae) and Leymus mollis (Poaceae) Spatial Segregation On Subarctic Coastal Dunes. Am. J. Bot. 2002, 89, 479-485. [CrossRef] [PubMed]

12. Kaźmierczakowa, R.; Bloch-Orłowska, J.; Celka, Z.; Cwener, A.; Dajdok, Z.; Michalska-Hejduk, D.; Pawlikowski, P.; Szczęśniak, E.; Ziarnek, K. Polish Red List of Pteridophytes and Flowering Plants; Institute of Nature Conservation PAS: Kraków, Poland, 2016.

13. Łabuz, T.A. Initial foredune field as a factor of accumulative character of coastal dunes of the Swina Gate Barrier (west Polish coast). Oceanol. Hydrobiol. Stud. 2003, 32, 39-58.

14. Ager, T.A.; Ager, L.P. Ethnobotany of the Eskimos of Nelson Island, Alaska. Arct. Anthropol. 1980, $17,26-48$.

15. Ootoova, I.; Atagutsiak, T.Q.; Ijjangiaq, T.; Pitseolak, J.; Joamie, A.; Joamie, A.; Paptsie, M. Interviewing Inuit Elders. Perspectives on Traditional Health; Nunavut Arctic College: Arviat, NU, Canada, 2001; Volume 5, p. 304.

16. Sánchez-Vilas, J.; Philipp, M.; Retuerto, R. Unexpectedly high genetic variation in large unisexual clumps of the subdioecious plant Honckenya peploides (L.) Ehrh. Plant. Biol. 2010, 12, 518-525. [CrossRef]

17. Uno, Y.; Nakao, S.; Yamai, Y.; Koyama, R.; Kanechi, M.; Inagaki, N. Callus formation, plant regeneration, and transient expression in the halophyte sea aster (Aster tripolium L.). Plant. Cell Tissue Organ. Cult. 2009, 98, 303-309. [CrossRef]

18. Lee, C.W.; Glenn, E.P.; O'Leary, J. W. In vitro propagation of Salicornia bigelovii by shoot-tip cultures. Hortic. Sci. 1992, 27, 472. [CrossRef]

19. Papafotiou, M.; Martini, A.N.; Bertsouklis, K.F.; Majumder, D.A.N. Micropropagation of Atriplex halimus L. Acta Hortic. 2016, 1113, 207-210. [CrossRef]

20. Erişen, S.; Öncel, Z. In vitro propagation of the threatened plant Sphaerophysa kotschyana (Fabaceae), Inter simple-sequence-repeat (ISSR) analysis and salt tolerance of the regenerants. Austr. J. Bot. 2013, 61, 67-72. [CrossRef]

21. Martini, A.N.; Papafotiou, M. Micropropagation of Limoniastrum monopetalum L. Acta Hortic. 2016, 13, 195-200. [CrossRef]

22. Kharrazi, M.; Nemati, H.; Tehranifar, A.; Bagheri, A.; Sharifi, A. In vitro culture of carnation (Dianthus caryophyllus L.) focusing on the problem of vitrification. J. Biol. Environ. Sci. 2011, 5, 1-6.

23. Amor, N.B.; Hamed, K.B.; Debez, A.; Grignon, C.; Abdelly, C. Physiological and antioxidant responses of the perennial halophyte Crithmum maritimum to salinity. Plant. Sci. 2005, 168, 889-899. [CrossRef]

24. Grigoriadou, K.; Maloupa, E. Micropropagation and salt tolerance of in vitro grown Crithmum maritimum L. Plant. Cell Tissue Organ. Cult. 2008, 94, 209-217. [CrossRef]

25. Shi, X.L.; Han, H.P.; Shi, W.L.; Li, Y.X. NaCl and TDZ are two key factors for the improvement of in vitro regeneration rate of Salicornia europaea L. J. Integr. Plant. Biol. 2006, 48, 1185-1189. [CrossRef]

26. Joshi, M.; Mishra, A.; Jha, B. NaCl plays a key role for in vitro micropropagation of Salicornia brachiata, an extreme halophyte. Ind. Crops Prod. 2012, 35, 313-316. [CrossRef]

27. Ben Hamed, K.; Castagna, A.; Salem, E. Sea fennel (Crithmum maritimum L.) under salinity conditions: A comparison of leaf and root antioxidant responses. Plant. Growth Regul. 2007, 53, 185-194. [CrossRef]

28. Simona, L.; Cerasela, P.; Lazăr, A.; Maria, B. Influence of growth regulators on morphogenetic processes under in vitro condition. J. Hortic. For. Biotechnol. 2012, 16, 197-202.

29. Ali, A.; Afrasiab, H.; Naz, S.; Rauf, M.; Iqbal, J. An efficient protocol for in vitro propagation of carnation (Dianthus caryophyllus). Pak. J. Bot. 2008, 40, 111-121. 
30. Zalewska, M.; Miler, N.; Wenda-Piesik, A. Effect of in vitro topophysis on the growth, development, and rooting of chrysanthemum explants (Chrysanthemum grandiflorum Ramat. Kitam). J. Hortic. Sci. Biotechnol. 2010, 85, 362-366. [CrossRef]

31. Lu, C.Y.; Nugent, G.; Wardley, T. Efficient, direct plant regeneration from stem segments of chrysanthemum (Chrysanthemum morifolium Ramat. cv. Royal Purple). Plant. Cell Rep. 1990, 8, 733-736. [CrossRef] [PubMed]

32. Łabuz, T.A. Polish coastal dunes-Affecting factors and morphology. Landf. Anal. 2013, 22, 33-59. [CrossRef]

33. Singh, A.; Jani, K.; Kumari, P.; Agarwal, P.K. Effect of $\mathrm{MgCl}_{2}$ and double concentration of Murashige and Skoog medium on in vitro plantlet and root cultures generation in halophytic grasswort Salicornia brachiata. Plant. Cell Tissue Organ. Cult. 2014, 120, 563-570. [CrossRef]

34. Murashige, T.; Skoog, F. A revised medium for rapid growth and bioassays with tobacco tissue culture. Physiol. Plant. 1962, 15, 473-497. [CrossRef]

Publisher's Note: MDPI stays neutral with regard to jurisdictional claims in published maps and institutional affiliations.

(C) 2020 by the authors. Licensee MDPI, Basel, Switzerland. This article is an open access article distributed under the terms and conditions of the Creative Commons Attribution (CC BY) license (http://creativecommons.org/licenses/by/4.0/). 